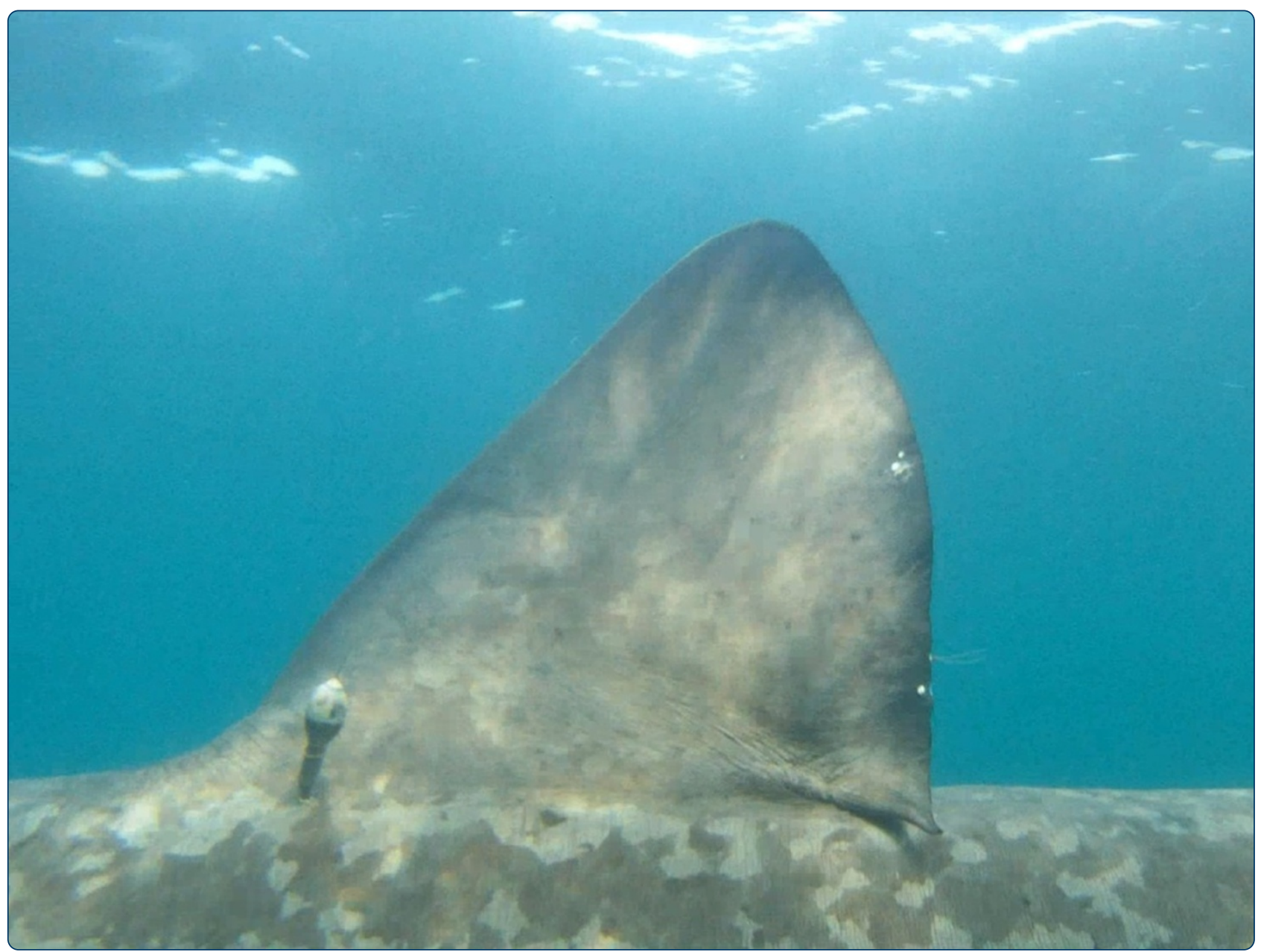

Eyes in the sky: linking satellite oceanography and biotelemetry to explore habitat selection by basking sharks

Curtis et al.

C Biomed Central 


\title{
Eyes in the sky: linking satellite oceanography and biotelemetry to explore habitat selection by basking sharks
}

\author{
Tobey H Curtis ${ }^{1,5^{*}}$, Stephan I Zeeman ${ }^{2}$, Erin L Summers ${ }^{3}$, Steven X Cadrin ${ }^{1}$ and Gregory B Skomal ${ }^{4}$
}

\begin{abstract}
Background: Satellite-based oceanographic data products are a valuable source of information on potential resource availability for marine species. Satellite oceanography data may be particularly useful in biotelemetry studies on marine species that feed at low trophic levels, such as zooplanktivorous whales, sharks, and rays. The basking shark, Cetorhinus maximus, is a well-documented zooplanktivore in the western North Atlantic, yet little is known of its movements and spatial ecology in this region. A combination of satellite tag technologies were used to describe basking shark movements with respect to concurrent satellite-observed oceanographic conditions in order to test for selection of these environmental variables.

Results: Satellite-linked 'smart' position only transmitting tags (SPOTs, $N=10$ ) were used to assess horizontal movements, activity space, and habitat selection, while pop-up satellite archival tags (PSATs, $N=7$ ) were used to describe depth preferences of basking sharks during summer and fall. The duration of SPOT tracks ranged from 5 to 45 days. Basking sharks used relatively small activity spaces in three focal areas off Massachusetts: Vineyard Sound, the Great South Channel, and Cape Cod Bay. These sharks appeared to select areas with shallow bottom depths, high primary production and chlorophyll concentrations, and steep surface gradients, but significant selection for these variables was only detected between mid-August and mid-October when the sharks were primarily located in Cape Cod Bay.

Conclusions: Basking sharks in the southern Gulf of Maine during summer and fall focus their activities in discrete areas likely to support high primary and secondary productivity. Habitat selection may also be influenced by mating and social activity at times, but further research is needed to differentiate these behaviors from foraging activity. Satellite-based biotelemetry and oceanography are powerful tools that together can provide valuable new insights into habitat selection patterns of highly mobile marine species.
\end{abstract}

Keywords: Cetorhinus maximus, Spatial ecology, Remote sensing, Zooplankton, Great south channel, Cape cod bay

\section{Background}

An ongoing challenge in the study of highly mobile marine animals is determining how they move through their dynamic environment and effectively locate and exploit patchy resources, particularly for species that prey upon pelagic zooplankton with ephemeral occurrence in space and time [1,2]. Large-bodied secondary consumers such

\footnotetext{
* Correspondence: Tobey.Curtis@noaa.gov

'Department of Fisheries Oceanography, School for Marine Science and Technology, University of Massachusetts - Dartmouth, Fairhaven, MA, USA ${ }^{5}$ National Oceanic and Atmospheric Administration, National Marine Fisheries Service, Greater Atlantic Regional Fisheries Office, Gloucester, MA 01930, USA Full list of author information is available at the end of the article
}

as baleen whales and filter-feeding sharks and rays must continually locate prey in sufficient densities to support their metabolic requirements, and in many cases, supply enough energy stores for extensive migrations: for examples, [3-6]. Baumgartner et al. [7] stated that this mode of 'feeding is often likened to grazing by cows...which is essentially correct if the cow is in the desert, looking for a small, continuously moving oasis of grass, blindfolded'. Accordingly, species that primarily rely on zooplankton for their survival must have well-adapted sensory systems highly-attuned to their environments and multiple behavioral and physiological mechanisms that allow them to locate productive habitats: for examples, $[8,9]$. 
The zooplanktivorous basking shark (Cetorhinus maximus Gunnerus 1765) is the second largest fish on earth, exceeding $10 \mathrm{~m}$ in length. In the western North Atlantic Ocean, they range from Newfoundland, Canada to Brazil $[5,10]$, but they have been observed most often during spring, summer, and autumn months off the northeastern US between Long Island, New York and the Gulf of Maine [11-14]. Beginning in late spring, basking sharks are frequently observed filter-feeding in productive patches of zooplankton, primarily comprised of calanoid copepods [12,15]. Analysis of sightings data from the Gulf of Maine and Bay of Fundy indicate that basking sharks may seasonally shift their distributions in relation to environmental variables (depth, temperature, chlorophyll concentrations, circulation patterns) that influence the distribution of their copepod prey $[12,16]$. However, individual movement and habitat selection patterns within these areas have not been examined.

Satellite-based technology to track the movements of large sharks and other fishes in their natural environment has only recently developed $[17,18]$. Important insights on habitat selection, migration, population structure, physiology, foraging strategies, and swimming behaviors can be inferred by examining the movements of individuals within a population [17-19]. The use of satellite telemetry methods to track sharks expanded rapidly over the last decade [3,18,20-22]. Basking sharks are particularly amenable to tagging and telemetry studies, because they are large and slow-moving in surface waters, making them accessible to researchers. Accordingly, the first satellite tracking experiment on a shark was conducted on a basking shark [23]. A single 7-m shark was tracked over a 17-day period off the coast of Scotland, and its movement path was compared to satellite imagery of sea surface temperature (SST) [23,24].

More recently, several studies have deployed pop-up satellite archival tags (PSATs) to investigate longterm, large-scale movements and habitat use of basking sharks tagged in the eastern North Atlantic [8,25-29] and western North Atlantic [5,30]. These studies demonstrated the ability of basking sharks to make extensive movements $(>6,000$ to $9,000 \mathrm{~km}$ in some individuals) away from summer feeding grounds [5,29]. Sims et al. [8] also compared PSAT-derived tracks of seven basking sharks to a modeled prey field off the British Isles and showed that the sharks consistently selected regions with high estimates of copepod biomass. However, direct comparisons between shark movements and concurrent environmental conditions were not possible due to the large geolocation errors associated with PSATs: for examples, [31] and the nature of the long-term zooplankton data set that was interpolated [8].
Investigations into more short-term or meso-scale movement patterns of basking sharks have received little additional study since Priede [23]. Sims and Quayle [32] visually tracked the fine-scale movements of basking sharks in the English Channel relative to in situ measurements of zooplankton density and small-scale thermal fronts. These visual methods were also used to estimate swimming speeds and threshold foraging behaviors, suggesting that basking sharks select and track patches of habitat with zooplankton densities $>0.6 \mathrm{~g} \mathrm{~m}^{-3}$ $[33,34]$. However, samples sizes remained small and track durations were short ( $<7$ hours) in these studies.

No other studies have investigated meso-scale (days to weeks) movement patterns of basking sharks using acoustic or satellite telemetry methods, or directly compared these movements to near real-time habitat conditions (for example, in situ measurements or remotely-sensed observations); and all previous work on shorter-term movements was conducted only in the eastern North Atlantic [23,32-34]. Given such limited information, the goal of this study was to track the meso-scale movements of basking sharks in their summer and fall foraging grounds in the southern Gulf of Maine using satellite telemetry and compare those movements to concurrent oceanographic conditions measured by satellites. We tested the hypothesis that basking shark habitat use in this region is non-random with respect to a suite of remotely-sensed environmental variables. Directly comparing the movements of multiple sharks to concurrent habitat conditions at comparatively high resolution is expected to provide further insights into the environmental features to which they orient and how they respond to changing conditions.

\section{Results}

\section{Movements}

The number of days satellite-linked 'smart' position only transmitter (SPOT)-tagged sharks were tracked ranged from 5 to 45 days (mean $=16.3$ days), resulting in a cumulative total of 163 tracking days (Table 1). A total of 547 Argos positions (location classes 0, 1, 2, and 3$)$ were received. The mean $( \pm 1 \mathrm{SD})$ time interval between position fixes was $6.9 \pm 10.7$ hours (median $=$ 1.8 hours). Once the Argos positions were filtered, 328 positions remained, and the mean time interval between positions changed to $12.2 \pm 13.6$ hours (median $=7.1$ hours).

Total track distances varied with duration, but ranged from 67 to $946 \mathrm{~km}$ (Table 1). Daily track distances ranged from 10 to $22 \mathrm{~km} \mathrm{~d}^{-1}\left(\right.$ mean $=17.0 \pm 3.7 \mathrm{kmd}^{-1}$ ) (Table 1). The mean rate of movement of the sharks was $1.53 \pm 1.34 \mathrm{kmh}^{-1}\left(0.43 \pm 0.37 \mathrm{~ms}^{-1}\right)$, and $99 \%$ of observed movement rates were less than $3.0 \mathrm{kmh}^{-1}\left(0.83 \mathrm{~ms}^{-1}\right)$. During Months A (17 June to 16 July) and B (17 July to 16 August), the tracked sharks primarily used the waters of 
Table 1 Summary of satellite-tagged basking sharks used in this study

\begin{tabular}{|c|c|c|c|c|c|c|c|}
\hline Shark & Tag type & Total length (m) & Date tagged & Duration (days) & $\begin{array}{l}\text { Number of } \\
\text { Argos positions }\end{array}$ & $\begin{array}{l}\text { Track } \\
\text { distance (km) }\end{array}$ & $\begin{array}{l}\text { Mean rate of } \\
\text { movement }\left(\mathrm{kmh}^{-1}\right)\end{array}$ \\
\hline B1 & SPOT & 7.2 & 18 Jun 05 & 10 & 51 & 152 & 1.30 \\
\hline B2 & SPOT & 8.2 & 3 Jul 05 & 9 & 17 & 132 & 1.80 \\
\hline B3 & SPOT & 6.4 & 3 Jul 05 & 17 & 49 & 256 & 1.13 \\
\hline B4 & SPOT & $?$ & $21 \mathrm{Jul} 05$ & 36 & 84 & 701 & 1.29 \\
\hline B5 & SPOT & 7.1 & $21 \mathrm{Jul} 05$ & 17 & 42 & 324 & 1.72 \\
\hline B6 & SPOT & 5.9 & 26 Aug 05 & 45 & 177 & 946 & 1.64 \\
\hline B7 & SPOT & 7.2 & 26 Aug 05 & 8 & 47 & 148 & 2.03 \\
\hline B8 & SPOT & 6.7 & 3 Oct 05 & 5 & 26 & 109 & 2.48 \\
\hline B9 & SPOT & 6.7 & 3 Oct 05 & 9 & 34 & 138 & 1.58 \\
\hline B10 & SPOT & 8.8 & 3 Oct 05 & 7 & 20 & 67 & 1.21 \\
\hline 53328 & PSAT & 7.2 & 18 Jun 05 & 79 & Depth only & & \\
\hline 53329 & PSAT & 8.1 & 3 Jul 05 & 98 & Depth only & & \\
\hline 52555 & PSAT & $?$ & $21 \mathrm{Jul} 05$ & 82 & Depth only & & \\
\hline 52566 & PSAT & 7.7 & $21 \mathrm{Jul} 05$ & 78 & Depth only & & \\
\hline 52561 & PSAT & 7.1 & $21 \mathrm{Jul} 05$ & 80 & Depth only & & \\
\hline 52556 & PSAT & 7.3 & $21 \mathrm{Jul} 05$ & 68 & Depth only & & \\
\hline 52560 & PSAT & 7.0 & 26 Aug 05 & 42 & Depth only & & \\
\hline
\end{tabular}

Data from the PSAT-tagged sharks were only used to describe the water column depth distribution of basking sharks during the study period. The 'Duration' column for the PSAT-tagged sharks refers to the number of days used in the depth distribution analysis, and only includes data from the same time period that SPOT-tagged sharks were tracked in the study site.

Vineyard Sound (shark B1 only), the Great South Channel, and Nantucket Shoals (Figure 1a, b), while later in the season during Months C (17 August to 16 September) and D (17 September to 16 October), the sharks moved into Cape Cod Bay and southern Stellwagen Bank areas (Figure 1c, d). Movements tended to be highly localized, with cumulative activity space (minimum convex polygon area) in each month ranging from approximately $1,561 \mathrm{~km}^{2}$ in Month D to $13,824 \mathrm{~km}^{2}$ in Month B (Figure 1). Activity space was even smaller during some periods. For example, from 1 to 10 October (during Month D), basking sharks B6, B8, B9, and B10 all focused their movements in an area only approximately $110 \mathrm{~km}^{2}$ off the northwestern tip of Cape Cod (Figure 2).

\section{Monthly habitat use and selection}

All basking shark movements were restricted to continental shelf waters $(<200 \mathrm{~m})$ (Figure 2). Mean monthly bottom depths over which the tracked sharks occurred were 53 to $94 \mathrm{~m}$, and mean depth gradients were 2.2 to 4.7\%. Vertical distribution data from the seven PSATtagged basking sharks indicated that during this time period in the study site, the sharks tended to spend the majority of their time in the upper water column (Figure 3). On average, basking sharks spent $66.4 \%$ of the time in the upper $25 \mathrm{~m}$ of the water column, with $43.3 \%$ of their time at less than $10 \mathrm{~m}$ (Figure 3). There was no discernible diel vertical migration pattern, with sharks predominantly using the upper water column during both day and night (Figure 3). We assumed that the ten SPOT-tagged basking sharks had similar vertical behavior.

The distributions of the habitats used in each time period relative to what was determined as 'available' from the randomization procedure varied from month to month (Figure 4). The habitats occupied by tagged sharks had mean monthly SSTs of 13.1 to $19.8^{\circ} \mathrm{C}$, chlorophyll-a (Chl-a) concentrations of 0.9 to $2.8 \mathrm{mg} \mathrm{L}^{-1}$, and net primary production (PP) levels of 2,177 to $3,409 \mathrm{mg} \mathrm{C} \mathrm{m}^{-2}$ $\mathrm{y}^{-1}$ (Figure 4). In most periods, there were only weak associations with surface fronts based upon SST and Chl-a gradients or the front probability index (Figure 4). Mean monthly use was 2.2 to $14.4 \%$ for Chl-a gradient, 5.2 to $13.1 \%$ for SST gradient, and 0.01 to 0.06 for the front probability index.

Significant selection for particular variables was uncommon and also varied across months. No variables were found to be significant predictors of habitat selection during Months A and B, even at the most liberal probability level $(\alpha=0.50)$ (Figure 5). Habitat use largely matched the habitat available during these months. However, during Months $\mathrm{C}$ and D basking sharks showed indications of selection for shallower waters and areas with greater PP, Chl-a, and Chl-a gradients than what was available (Figure 4). Additionally, during Month $\mathrm{D}$, significant selection was detected for cooler waters $\left(13.1 \pm 8.6^{\circ} \mathrm{C}\right)$ than what was available (Figure 4). A notable drop in 


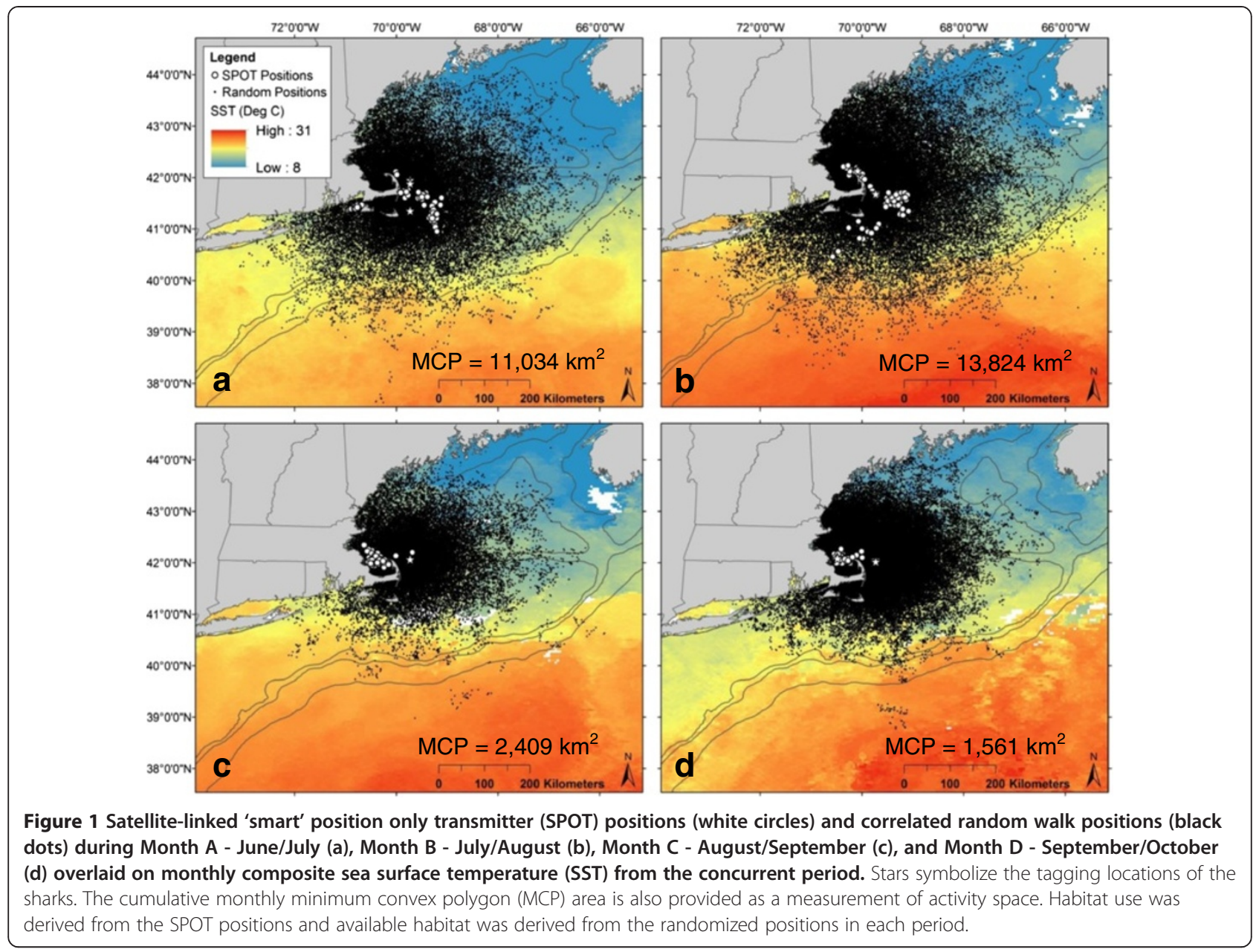

temperature occurred in the area used by the sharks in Cape Cod Bay between Months C and D (Figures 1, 4). There was also some indication of selection for areas with steeper SST gradients and lower front probability during Month D (Figure 4).

Collectively, the strongest habitat selection indicators during the monthly periods were PP (greater than random) and depth (shallower than random) (Figure 5). The movements of the basking sharks relative to PP in each month are plotted in Figure 6. Visual comparisons demonstrate that the sharks largely were found within or along the edges of some of the most highly productive areas in the study site (Figure 6). Chl-a concentration (greater than random), Chl-a gradient (steeper than random), SST gradient (steeper than random), and front probability (lower than random) were moderate habitat selection predictors (Figure 5). Except for Month D, SST was a poor predictor of habitat selection (Figure 5). Finally, bottom depth gradient tended to be the poorest habitat selection indicator (Figure 5).

\section{A week in the life of two basking sharks}

The week-long track segments selected for fine-scale analysis were from shark B4 (21 to 28 July 2005) and shark B6 (26 August to 2 September 2005). These segments included the most filtered SPOT positions in a seven-day period, had nearly complete satellite coverage, and were representative of the movements of other sharks.

Shark B4 was tagged $16 \mathrm{~km}$ east of Cape Cod, initially traveled to the northwest, but then moved back to the southeast toward the Great South Channel where it remained for the duration of this week-long track segment. The activity space for the track segment was $1,327 \mathrm{~km}^{2}$. This shark occupied a relatively narrow range of SST during this period $\left(18.1\right.$ to $20.3^{\circ} \mathrm{C}$ ) (Figure 4). Significant habitat selection was not detected for any environmental variable and most habitat use distributions were comparable to those in the monthly intervals (Figure 4). The only notable differences were in greater than expected values of front probability and lower than 


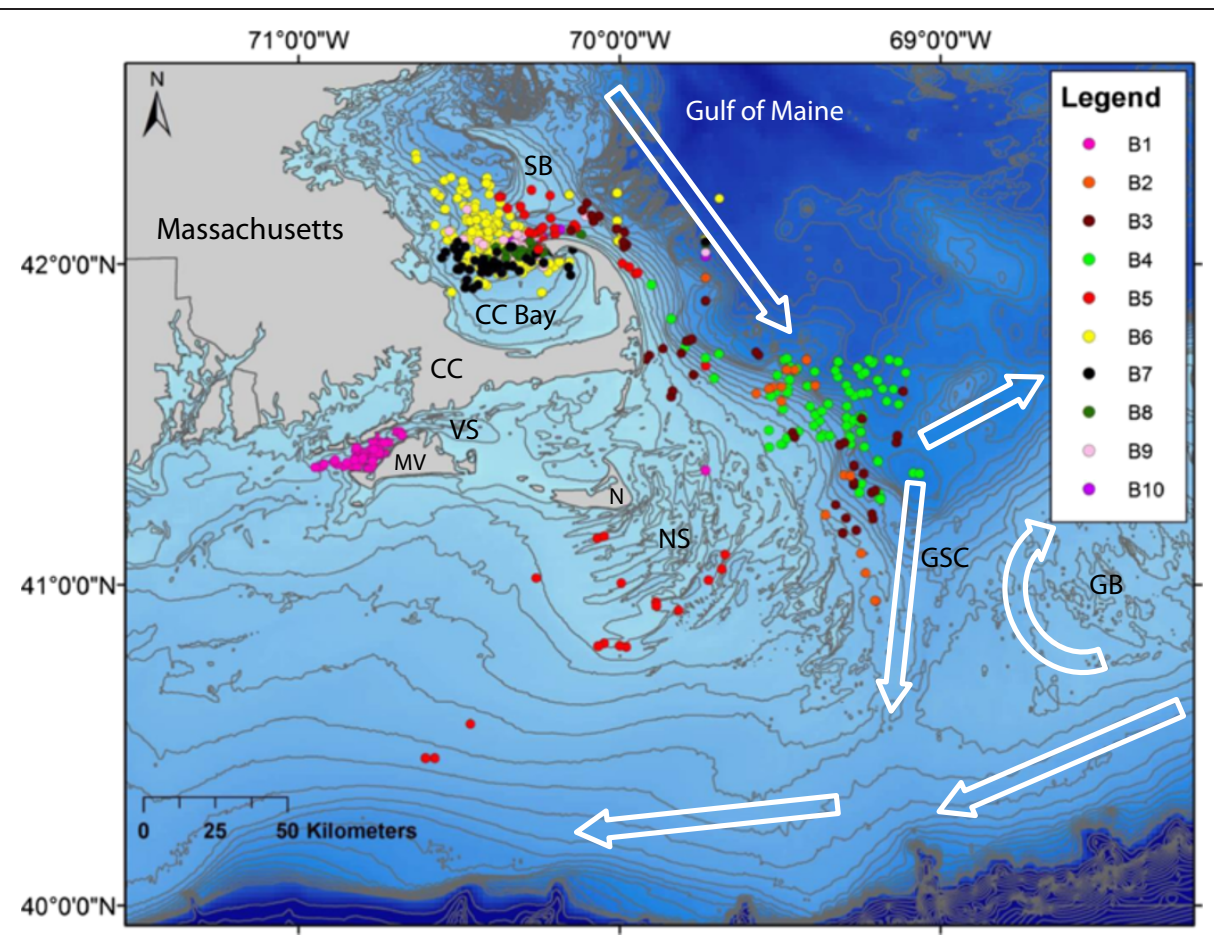

Figure 2 Argos locations of 10 satellite-linked 'smart' position only transmitter (SPOT)-tagged basking sharks overlaid on detailed bathymetry (10-m contours) off Massachusetts between 18 June and 12 October 2005. CC = Cape Cod, SB = Stellwagen Bank, MV = Martha's Vineyard, VS = Vineyard Sound, N = Nantucket, NS = Nantucket Shoals, GSC = Great South Channel, and GB = Georges Bank. The white arrows indicate the major surface current circulation pathways during the study.

expected values for Chl-a and PP (Figure 4). The area used by this shark in the Great South Channel appeared to be adjacent to, rather than within, a high Chl-a and PP area over Nantucket Sound and Nantucket Shoals.

The week-long track segment for shark B6 started $25 \mathrm{~km}$ off the northeast side of Cape Cod. It swam to

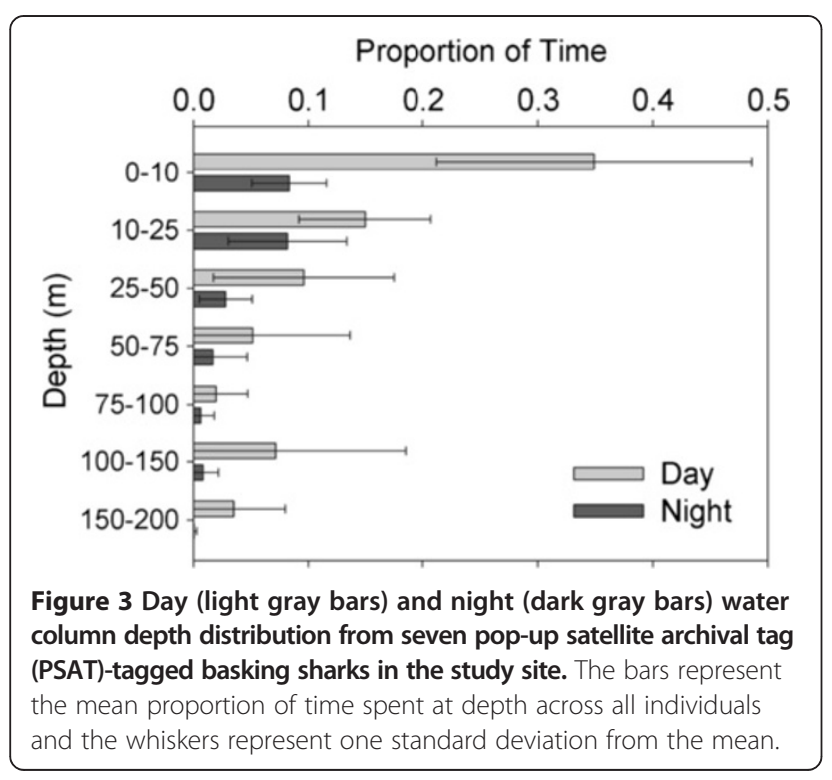

the west and spent most of this track segment (as well as the remainder of its 45-day track) in northern Cape Cod Bay. The activity space during this week was small $\left(644 \mathrm{~km}^{2}\right)$ and the SST range occupied was also relatively narrow (19.1 to $20.5^{\circ} \mathrm{C}$ ) (Figure 4). Significant selection (at $\alpha=0.50$ only) was detected for shallower than expected depths and higher than expected values of Chl-a and PP (Figure 4). During this week, Cape Cod Bay had the highest PP levels $\left(>5,000 \mathrm{mg} \mathrm{C} \mathrm{m}^{-2} \mathrm{y}^{-1}\right)$ in proximity to the starting location of $\mathrm{B} 6$ and the shark clearly appeared to prefer this area. Habitat use distributions for all other variables were comparable to the monthly intervals (Figure 4).

\section{Discussion}

Recent technological advancements have provided researchers with new tools to investigate the movements and behavior of highly mobile marine species like sharks [17-19] and have given us unprecedented views into the dynamic environment that they occupy $[35,36]$. Satellitebased biotelemetry, when combined with satellite-based environmental observation, has the potential to vastly improve our understanding of the ecology of enigmatic marine species [6,37-39]. Despite the utility of using remotely-sensed sea surface measurements when studying the large-scale movements of sharks, their use has been 


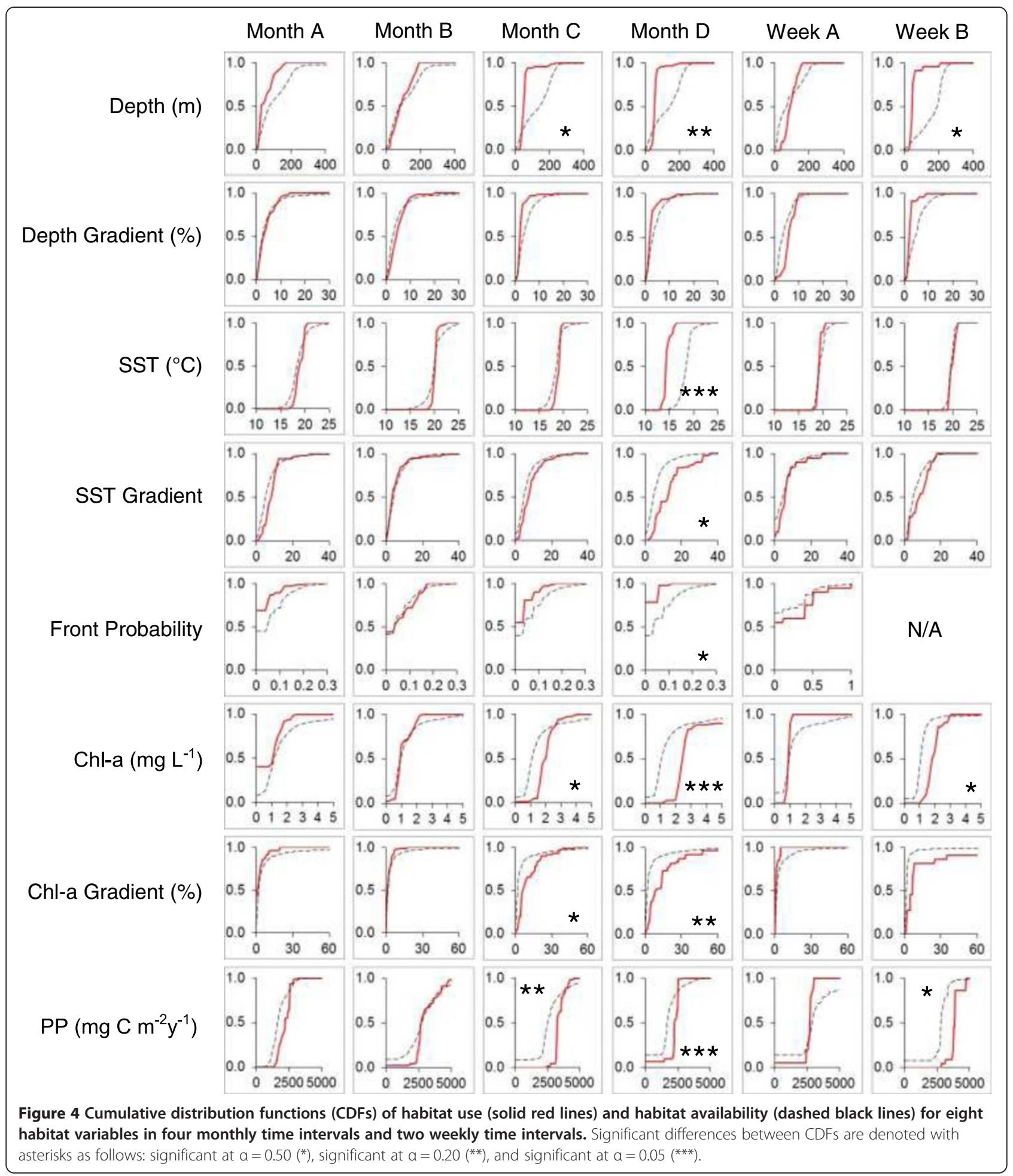

limited to visually overlaying tracks on SST $[20,24,30,40]$ or analyzing few available variables $[6,21,25]$. Though this approach can be informative, more quantitative analytical techniques can identify patterns that are not detectable from simple visual comparisons $[37,39,41]$. Research on these species should strive to more explicitly account for numerous habitat variables because many biotic and abiotic factors interact to influence resource availability, especially for species that feed at low trophic levels (such as zooplanktivores) [37,39,41,42]. We used a 


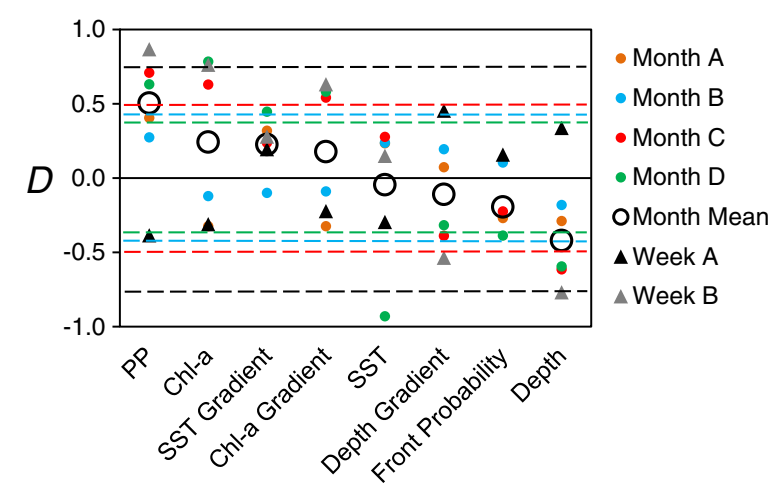

Figure 5 Monthly mean-ranked values of $D_{\max }$ for eight habitat variables derived from the cumulative distribution functions (CDFs) in Figure 4. $D_{\max }$ values greater than zero indicate habitat use values higher than expected, while $D_{\max }$ values less than zero indicate habitat use values lower than expected. The dashed lines indicate the critical values of $D_{\max }$ at $a=0.50$ (minimum significance level) for the appropriate sample size $(\mathrm{N})$ in each time period. The blue dashed line is for Months $A$ and $B(N=3)$, the red dashed line is for Month $C(N=2)$, the green dashed line is for Month $D(N=4)$, and the black dashed line is for Weeks $A$ and $B(N=1)$.

combination of satellite biotelemetry data and satellitebased oceanographic observations, to gain new insights into habitat selection patterns by basking sharks at comparatively high spatiotemporal resolution. This is the first time SPOT tags have been used to study detailed movement patterns of basking sharks in the western North Atlantic.

A challenging tradeoff to consider with this approach to habitat selection is the temporal scale of analysis. This needs to be considered with respect to the time periods covered by tracking and the availability and coverage levels of the selected satellite oceanographic data. Longer time intervals (monthly or seasonal time scales) may be advantageous for providing more tracking positions (that is, more potential statistical power) and satellite coverage is likely to be complete. Depending on the total duration of the tracking period, it also results in fewer time intervals to statistically analyze, making data management, analysis, and interpretations simpler. However, oceanographic conditions are rarely static in space and time, and the longer the time period selected, the more diluted sea surface features may become due to blending and averaging of the satellite data. Given our data, we selected month-long intervals so that all of the available tracking data could be included and consistent intervals could be used for all remotely sensed observations. Examining a subset of tracks at a finer, week-long interval generally did not improve significance over those examined at the monthly interval. The reasons for this are unclear, but could be related to the small number of tracking positions available for analysis at that temporal scale.
These tradeoffs should be carefully considered on a case by case basis, but the optimal balance should allow use of the maximum amount of tracking data while simultaneously minimizing dilution of environmental observations.

Basking sharks have the capacity to make long-distance movements spanning thousands of kilometers [5,29]. By comparison, the summer/fall activity spaces documented in this study are much smaller. The sharks tracked in this study constrained their movements to small, discrete areas and showed signs of strong site attachment spanning days to weeks. The slower rates of movement and repeated back-and-forth movements of these sharks, such as shark B1 in Vineyard Sound in Month A and sharks B6 to B10 during Months C and D in Cape Cod Bay, suggest area-restricted searching behavior, a pattern that occurs in a variety of species when in the presence of abundant resources $[8,43]$. Given our general understanding of why basking sharks occur in this region [12-14], it is most likely these sharks were orienting to food (that is zooplankton) and/or conspecifics (for mating or socialization).

Our results suggest that shallow bottom depths (that is, continental shelf waters) and high PP can be important indicators of summer/fall habitat for basking sharks off New England. Basking sharks are widely known for their seasonal occurrence in such productive coastal areas $[10,13,16,44]$. Chl-a concentration and surface gradients (Chl-a, SST) also appear to contribute to habitat selection at times. Chl-a and PP are highly correlated with each other [45], so it was expected that if one variable was significant, the other would be also. These measures of primary production (that is, phytoplankton abundance) are indirect indicators of zooplankton abundance, since the dominant pelagic zooplankton species in this region are reliant upon grazing of phytoplankton [46]. Although not necessarily reliable in all times and areas, remotely-sensed PP and Chl-a are likely the most useful satellite observations with which to study basking shark distributions due to their correlation with basking shark prey. While SST (approximately 13 to $20^{\circ} \mathrm{C}$ ) is likely an important predictor of the seasonal presence of basking sharks [12], it did not appear to significantly influence habitat selection at finer scales within the study site.

It is important to recognize that the variables used in this study were only indirect indicators of potential habitat suitability and not necessarily features to which the sharks were orienting. The oceanographic features we analyzed are only partially correlated with the density of potential zooplankton prey [25,45-47] and may not show any correlation to other potential resources (for example, conspecifics). The indirect measure of zooplankton density may explain why significant selection 


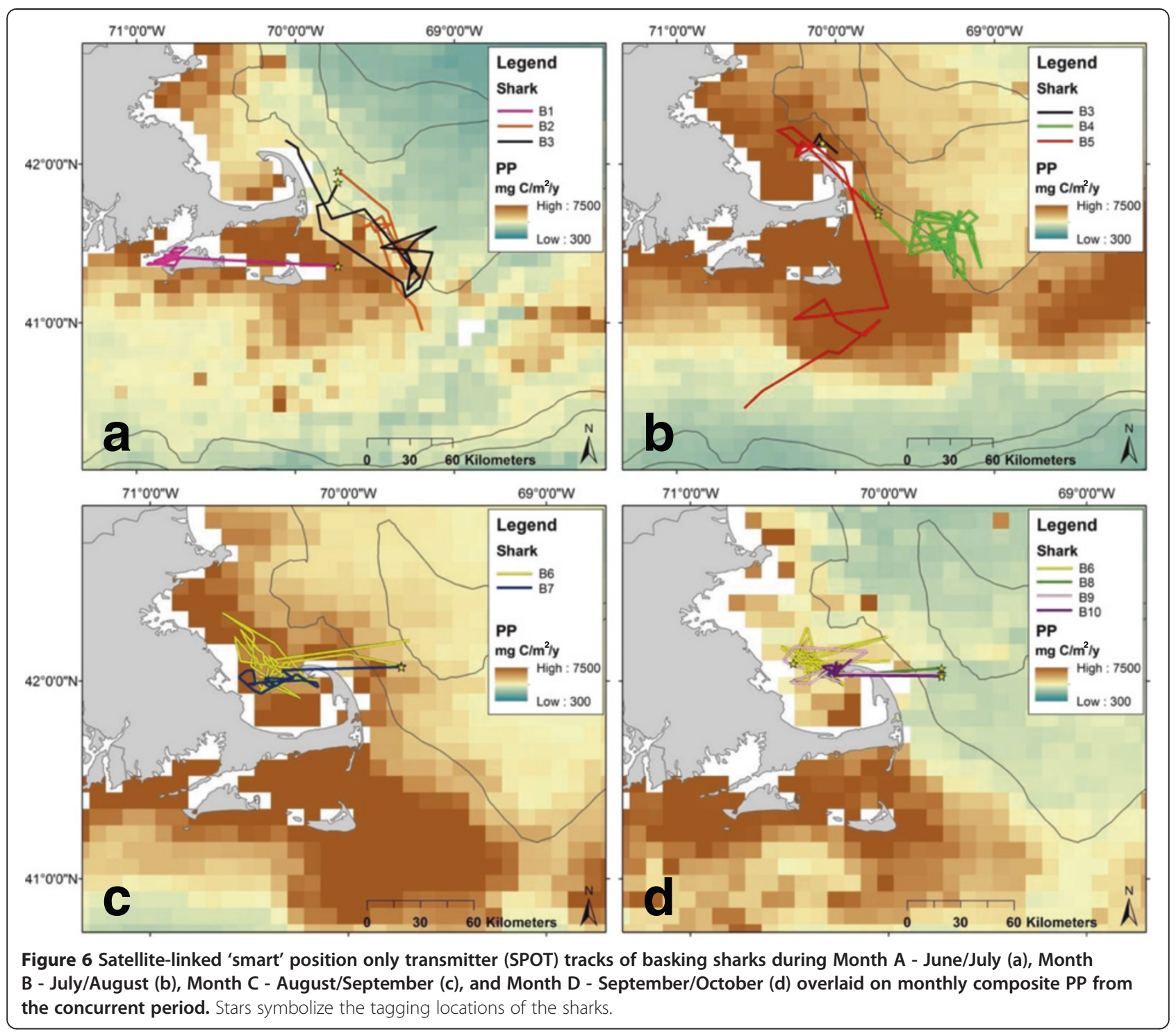

was not detected for any variables in Months A and B (mid-June to mid-August). During this time period, the tracked sharks primarily used the Great South Channel and Nantucket Shoals area. Aggregations of zooplankton, particularly the dominant copepod Calanus finmarchicus, in this area are largely driven by advection processes (that is, current circulation) that collect copepods from the Gulf of Maine and flow southward to the Great South Channel where surface convergences cause them to cluster $[2,48]$. Therefore, even though the sharks may have been foraging in a productive patch of zooplankton, the physical processes promoting that productivity were not directly correlated to the satellite variables we analyzed. Similar challenges have been documented in modeling North Atlantic right whale (Eubalaena glacialis) occurrence in the Great South Channel [48].
Direct estimation of zooplankton abundance and composition can only be done with in situ measurements: for example, $[46,47,49,50]$, but ongoing zooplankton surveys can provide interpolated surfaces that can be analyzed in a similar fashion as remotely-sensed data [8,51]. Sims et al. [8] demonstrated with one such zooplankton survey that basking sharks consistently occupied regions with the highest available biomass of copepods off the British Isles. Therefore, basking sharks themselves may serve as 'biological plankton recorders' [32], in that their presence in an area may at times be a better predictor of zooplankton abundance than any of the available oceanographic data sources. Similar comparisons between basking shark movements and zooplankton survey data should be attempted in other regions where these data are available. 
Some aggregations of basking sharks in the Great South Channel have been hypothesized to be associated with courtship and mating, rather than foraging [14]. In the North Atlantic, most evidence of courtship and mating behavior has been observed between May and July [52-54]. However, the possible mating aggregations in the Great South Channel [14] occurred during September and October, outside the hypothesized mating season. If the sharks tracked in the Great South Channel between June and August (Months A and B) were associating with conspecifics for courtship and mating, that could also explain the apparent lack of correlation with oceanographic features during that period. Little is known about the reproductive cycle of basking sharks in the western North Atlantic and mating activity could occur over a longer time period and broader area than has been described [14]. Additionally, foraging and mating activities may occur concurrently in this species. However, it is likely that during periods when habitat selection is driven by proximity to conspecifics rather than proximity to abundant zooplankton prey, the correlation to oceanographic variables might be diminished.

Additional research is necessary to determine whether basking shark focal habitats off New England are related solely to foraging or if mating or other social activities are also important for habitat selection at times. However, it may prove impossible to address this with only remote sensing and telemetry. Evidence of courtship and mating can typically only be found from visual observation $[14,53]$ or examination of reproductive organs from dead specimens [52].

The more significant selection indices for PP and Chl-a during Months C and D (mid-August to midOctober) indicate that resources used by the basking sharks in Cape Cod Bay were more highly correlated to those variables and, most likely, associated with prey. As resources in the Great South Channel may have become depleted or dispersed by the end of Month B, the sharks transitioned to Cape Cod Bay where high PP and Chl-a may have been indicators of high zooplankton abundance [51]. However, direct correlation between satellite-derived PP or Chl-a estimates and zooplankton abundance are variable $[25,45,46]$. Also, given the close proximity of multiple tagged sharks in Cape Cod Bay and the small activity spaces they concurrently occupied, we cannot completely preclude mating or socialization activity from influencing habitat selection in that period. Therefore, selection for certain environmental variables may vary among areas and time periods. Other site-specific processes could influence resource distributions and resultant movement patterns.

Given the results of previous work [14,16,24,32,54], it was expected that SST gradient and front probability measures (i.e., thermal fronts) would be more significant habitat selection indicators. Thermal fronts are widely known to physically aggregate zooplankton and, hence, zooplankton predators: for example, $[24,32,48]$. The fact that these variables did not appear more significant in our analysis does not necessarily mean basking sharks do not orient to thermal fronts in this region. It is more likely that the spatial and temporal resolution of the satellite observations we used were too coarse to capture smaller-scale surface features $(<5$ to $10 \mathrm{~km})[32,48]$. More persistent, larger-scale tidal and shelf-slope fronts, as well as the Gulf Stream edge, are more detectable by satellites and tracked sharks appeared to prefer the cold side of the shelf-slope front in the Great South Channel during Months A and B. Basking shark aggregations have been documented in this persistent frontal region during fall [14], but sharks were found on one side of the front or the other and not necessarily within the zone with the steepest gradients. Spatial resolution is a limitation of using satellite oceanography in habitat use studies, in that it cannot be used to resolve habitat associations that occur at a smaller scale than the resolution of the environmental measurement. Visual overlays of tracks on environmental surfaces using GIS remain an essential aspect of interpreting movement patterns.

Using data from PSATs, we found that basking sharks primarily preferred the upper water column $(<25 \mathrm{~m})$ during the study period, which validated the use of remotely-sensed surface measurements to study habitat selection in this region. Had these sharks spent more time at greater depths, there would likely be less relevance to using sea surface observations. Basking sharks have been documented to spend significant amounts of time at mesopelagic depths $(>200 \mathrm{~m})$ during certain times of the year $[5,29]$, so incorporating some insights into vertical behavior in the study site was a necessity. However, since the zooplankton assemblage in the Great South Channel and Cape Cod Bay can have varying vertical structure, including aggregation around the thermocline and near the bottom [50,55-57], subsurface conditions may also influence habitat selection at times.

The apparent lack of a diel vertical migration pattern of the basking sharks we tagged during this period suggests that either they were not associating with vertically-migrating resources or their focal prey may not have been vertically migrating during the study period. Normal and reverse diel vertical migration patterns were detected in PSAT-tagged basking sharks in the eastern North Atlantic; these patterns reflected the site-specific vertical migration strategy of the available prey [26]. However, the variable and energetic hydrographic patterns around Cape Cod $[48,58]$ and the considerable inter- and intra-specific variability in zooplankton vertical migration patterns in this region [59] tend to keep prey available in 
surface waters during both day and night. During some periods in this region, copepods have been documented to remain in surface waters throughout the day and display no vertical migration [60].

With additional data collection on basking shark movements and habitat use, it may be possible to model habitat preferences using more advanced composite, mixed, or additive models that account for multiple variables simultaneously: for example, $[6,37,38]$. Improving the correlation of remotely-sensed physical variables to zooplankton abundance patterns would be a beneficial step in this process. Such modeling could then be used to better predict basking shark distributions based upon only remotely-sensed environmental observations or, furthermore, predict how distributions may shift under changing climate conditions [16,61]. Zooplankton distribution and population dynamics in this region are intricately connected with climate patterns $[1,46,47]$ Therefore, given the projected impacts of global warming on the western North Atlantic, including higher surface and bottom temperatures, increased stratification of the water column, changes in circulation patterns, shifting timing of phytoplankton blooms, and possible declines in primary productivity [62-65], bottom-up ecological impacts may be more dramatically experienced for zooplanktivores like the basking shark. Given the ongoing conservation concerns for basking sharks [44] and their potential vulnerability to climate change, more research on movements and habitat selection will help inform conservation strategies. Studies linking satellite biotelemetry and oceanography provide a powerful means to address these concerns.

\section{Conclusions}

This is the first study to examine detailed movements of basking sharks in their summer/fall habitats in the western North Atlantic. High resolution movements from SPOT-tagged sharks were compared to satellite-based oceanographic measurements concurrent with the periods of tracking, thereby providing new insights into environmental factors that influence habitat selection in this region. PSATs were also used to reveal that basking sharks primarily used near-surface waters during the study period, validating the use of remotely-sensed surface observations. Examination of a subset of tracks at 7-day intervals did not improve statistical significance of habitat selection as compared to 30-day intervals. However, this temporal tradeoff should be considered on a case by case basis in future studies. Satellite-based estimates of PP, Chl-a concentrations, and surface gradients were the best habitat predictors, but use of these variables can be confounded by site-specific physical circulation patterns and/or at times when sharks may be associating with conspecifics. Basking sharks focus their activities in discrete areas with high productivity, but additional research is necessary to better link satellite oceanographic data with zooplankton community distributions in this region.

\section{Methods}

\section{Tag design and deployment}

The primary tags used in this study were towed satellitelinked 'smart' position-only transmitting tags (SPOT4, Wildlife Computers, Redmond, WA, USA), which transmit a radio signal to the Argos satellite system whenever the tag's antenna is above the water's surface. The satellites then calculate the tag's geographic location (latitude and longitude) by measuring the Doppler shift of the transmission frequency and the information is relayed to the investigator (refer to: http://www.argos-system. org). A 'location class' is assigned to each detection, indicating the approximate mean error associated with the position estimate [66]. Argos positions were filtered so that higher-accuracy 0 (mean error $=5.6 \mathrm{~km}), 1$ (mean error $=1.0 \mathrm{~km}), 2$ (mean error $=0.8 \mathrm{~km})$, and 3 (mean error $=0.4 \mathrm{~km}$ ) location classes were used [66].

SPOT tags were attached to ten free-swimming basking sharks (5.9 to $8.8 \mathrm{~m}$ total length) between June and October 2005 using the harpoon technique described by Chaprales et al. [67] (Table 1). A stainless steel dart anchor was harpooned approximately $10 \mathrm{~cm}$ into the dorsal musculature near the base of the first dorsal fin. The tags were attached to the anchor by a $1.5-\mathrm{m}$ cable tether and trailed above the shark's dorsum as it swam. For buoyancy, each tag was mounted on a custom-built syntactic foam base, which was counterweighted with a wooden keel with a lead core for hydrodynamic stability. Tags could break the water's surface and communicate with the satellites whenever the shark was within approximately $1 \mathrm{~m}$ of the surface.

Seven additional basking sharks were tagged with PSATs (PAT4, Wildlife Computers, Redmond, WA, USA) to provide insights into depth distribution of the sharks during the study period (Table 1). These sharks were tagged during the same time period in the same locations as those with the SPOT tags [5], and, therefore, serve as reasonable proxies for the vertical movements of the SPOT-tagged sharks. Depth, temperature, and geolocation data from the PSATs were examined, and only depth distribution data during the sharks' summer/fall residency in the Gulf of Maine region were included in this analysis. Due to the comparatively low positional accuracy associated with PSATs [31], these sharks were not included in any horizontal movement or habitat selection analyses (Table 1 ).

All shark tagging methods followed internationally recognized guidelines on animal ethics, and complied with Massachusetts Division of Marine Fisheries regulations. 


\section{Environmental observations}

The study area was the waters off Cape Cod, Massachusetts, USA, in the western North Atlantic Ocean (Figure 2). The region is a productive continental shelf ecosystem well-known for its commercial and recreational fisheries: for example, [11]. The region has SSTs that typically range annually between 6 and $24^{\circ} \mathrm{C}$ [68]. Nutrient fluxes and large-scale horizontal and vertical oceanographic processes (for example, surface currents, shelf-slope fronts, tidal mixing fronts, riverine freshwater inputs) lead to seasonal plankton blooms and high overall biological productivity $[2,46,50,51,55]$. Additionally, localized hydrographic patterns create dynamic small-scale features (for example, thermal fronts, density gradients) that are known to concentrate zooplankton $[56,57,69]$.

The use of satellite-based sea surface observations is particularly practical because SPOT tags only provide positional information when the tagged animal is at the ocean's surface. While remote sensing cannot provide insights into physical or biological gradients below the surface, matching surface conditions to surface-oriented shark positions allows direct comparisons between the sharks and the environmental conditions they encountered at the surface. Since zooplankton density cannot be directly estimated via satellite observation, other surface features were used as indicators of areas with high secondary productivity $[46,70]$. Consistent with other marine zooplanktivore habitat use studies $[6,16,39,41,42]$, the following environmental variables were selected to examine basking shark habitat use: bottom depth, bottom depth gradient, SST, SST gradient, oceanic front probability, chlorophyll-a (Chl-a) concentration, Chl-a gradient, and net primary production (PP). Gradients were estimated in ArcGIS as the maximum percent change across each cell and its adjacent cells $(3 \times 3$ cell gradients). Steeper surface gradients were considered to be indicative of frontal zones.

All satellite oceanography data during the study period were obtained from NOAA's CoastWatch, Environmental Research Division's Data Access Program (ERDDAP); metadata associated with each satellite and its sensors are available on the program's website (http://coastwatch.pfeg. noaa.gov/erddap/index.html). Measurements of SST were collected from NOAA's Polar-Operational Environmental Satellites (POES), Pathfinder v5.0 Advanced Very High Resolution Radiometer (AVHRR) satellite sensor [71]. Front probability was generated from NOAA's Geostationary-orbiting Operational Environmental Spacecraft (GOES-12) [70]. Chl-a concentration observations were collected from the National Aeronautics and Space Administration's (NASA) Aqua satellite with its Moderate Resolution Imaging Spectroradiometer sensor (Aqua-MODIS) [72]. Net primary production estimates were generated by combining POES SST measurements with Chl-a observations from the Sea-viewing Wide Fieldof-view Sensor (SeaWiFS) sensor on the GeoEye Orbview2 satellite [62]. Satellite observations had a geographic resolution of $0.05^{\circ}$ latitude $(5.6 \mathrm{~km})$ by $0.05^{\circ}$ longitude (approximately $4.1 \mathrm{~km}$ in the study site), except for PP which had a resolution of $0.1^{\circ}(11.2 \mathrm{~km})$ latitude by $0.1^{\circ}$ longitude (approximately $8.2 \mathrm{~km}$ ). We used the ETOPO1 Global Relief Model for ocean bathymetry in the study area, which has 1 arc-minute depth resolution [73].

The shortest consistent time intervals available for all satellite data sets during the study period were monthly composites. Therefore, the tracking data were broken into monthly intervals to match the temporal scale of the environmental observations. Monthly composites also maximized the satellite coverage for the study site, minimized the appearance of environmental data gaps due to cloud cover or other interference, and allowed full utilization of the tracking data. To most closely match the time periods when sharks were tracked, the monthly intervals were defined as follows: 17 June to 16 July 2005 (Month A); 17 July to 16 August 2005 (Month B); 17 August to 16 September 2005 (Month C), and 17 September to 16 October 2005 (Month D). All Argos positions from the tagged sharks were received during these periods. Month A included positions from three sharks (B1, B2, and B3), Month B included positions from three sharks (B3, B4, and B5), Month C included positions from two sharks (B6 and B7), and Month $D$ included positions from four sharks (B6, B8, B9, and B10).

\section{Movements and habitat selection}

SPOT tag positions less than two hours from the previous position were removed to reduce bias from serial autocorrelation and help normalize the distribution of track step intervals $[74,75]$. The two-hour minimum interval between SPOT positions represented a tradeoff between attempting to minimize autocorrelation [74,75] while still maintaining as many observations as possible for analysis, given the small overall sample size. Erroneous positions, including those on land or those that resulted in unrealistic rates of movement $\left(>10 \mathrm{kmh}^{-1}\right)$ were also removed: for example, [39]. Finally, a few positions $(\mathrm{N}=3)$ that were indicative of migratory movements out of the study site were removed (which are longer, directed steps, outside the activity space of all other positions). We assumed that the remaining positions, which were plotted using geographic information system (GIS) software (ArcGIS 10.0, ESRI), represented movements associated with local resources. Only the filtered positions were used in habitat selection analyses. Minimum convex polygons were calculated in ArcGIS to provide a measure of the activity space of the sharks over various intervals. 
Each SPOT tag position was assigned the satellite measurements of the underlying monthly composite environmental surfaces (SST, Chl-a, PP, etc.) using ArcGIS. Given the comparatively high positional accuracy of SPOT tags: for example, [66], and our approach of matching surfaceoriented shark positions to remotely-sensed sea surface conditions, we did not filter or interpolate tracks beyond the raw Argos locations (which could result in interpolated positions falling on habitats not actually occupied). If a position fell on a cell that lacked a satellite measurement (for example, due to cloud interference), the position was assigned the value of the nearest positive cell. This resulted in a distribution of observations representing habitat use of the sharks.

Habitat selection was quantified by comparing the use of a surface habitat type/feature to its availability: for example, $[75,76]$. To test for selection of the different habitat variables, a track randomization procedure was used $[8,41,77,78]$. To approximate habitat availability, 250 random walk simulations were generated for each track or track segment in each monthly period using the Geospatial Modeling Environment [79] and ArcGIS. Each random walk simulation was created by starting from the first track position of each shark and having step lengths and turning angles randomly drawn from the empirical distribution of observed steps and angles [79]. The number of steps generated for each random walk was set equal to the total number of observed steps in each monthly period. All random walks were constrained so that they did not fall on land. The 250 random walk simulations for each track resulted in a cloud of random points (approximately 34,000 to 94,000 points per monthly period) around each set of observed tracks, which we defined as the available habitat for that monthly period. Each random point was then assigned satellite environmental values in the same manner used for the tracking positions described above. Due to similarities in the areas utilized across sharks in each monthly period, all SPOT tag positions and their associated random walk points were pooled across individuals to examine habitat use and test for habitat selection. Pooling of observations was also necessary due to the small overall sample size; limiting the ability to conduct these analyses at the individual level (refer to Results).

Habitat selection was inferred when the observed use of a particular habitat variable was significantly different than what would be expected from random movements $[41,77,78]$. Cumulative distribution functions (CDFs) of habitat use and availability were generated for each independent environmental variable and time interval (that is, 8 variables $\times 4$ monthly periods $=32$ total comparisons). CDFs have several practical benefits for habitat selection analyses. Not only can they be used to visualize the range and cumulative frequencies of continuous observations, but they also avoid issues with the location and shape of distributions seen in common histograms $[80,81]$. Furthermore, they can also provide an indication of the directionality of the habitat used relative to the habitat available (that is demonstrate if the used values tended to be higher or lower than the available values). Significant differences between distributions can be tested with the nonparametric Kolmogorov-Smirnov test, which compares the maximum distance $\left(D_{\max }\right)$ between the two functions to established critical values for a given $\alpha$ $[80,81]$. The test is also practical when sample size is small, as in this study. We used the two-sample KolmogorovSmirnov test to identify significant differences between the CDFs of used (observed) and available (random) habitats [37]. Critical values for $D_{\max }$ were selected based on the number of sharks tracked in each monthly period $(\mathrm{N}=2$ to 4) [81]. Given the conservative degrees of freedom from the small sample size, we tested for significance at multiple probabilities $(\alpha=0.05,0.20$, and 0.50$)$. Using conservative and more liberal sets of critical values provided a range of significance in the habitat selection tests, helped reduce the risk of Type II error, and allowed us to rank the relative significance of the different independent variables.

For insights into habitat selection at an even finer temporal resolution, the two basking shark tracks with the most Argos positions and most complete satellite environmental coverage in a week-long period (a subset of the tracking positions analyzed at the monthly interval) were examined in relation to the same satellite observations described above. The week-long track segments were compared to seven-day composite SST, ten-day composite front probability, eight-day composite Chl-a, and eight-day composite PP covering the same week. The habitat selection procedures described above were repeated at the weekly scale for those two individual tracks. This analysis was also used to provide an assessment of whether the monthly composite approach resulted in weakened or diluted habitat use patterns due to the averaging of environmental observations over a longer time period.

\section{Abbreviations \\ AVHRR: Advanced Very High Resolution Radiometer; CDF: cumulative distribution function; Chl-a: chlorophyll-a; GIS: geographic information system; GOES-12: Geostationary-orbiting Operational Environmental \\ Spacecraft; MCP: minimum convex polygon; NASA: National Aeronautics and Space Administration; NOAA: National Oceanic and Atmospheric \\ Administration; POES: Polar-Operational Environmental Satellites; PP: primary production; PSAT: pop-up satellite archival tag; SPOT: satellite-linked 'smart' position only transmitter; SST: sea surface temperature.}

\section{Competing interests}

The authors declare that they have no competing interests.

\section{Authors' contributions}

GBS, SIZ, and ELS initiated the study and deployed the satellite tags on the sharks. THC, GBS, and SXC performed the data management and analysis. 
THC created the figures and tables, and drafted the manuscript. All authors edited, read, and approved the final manuscript.

\section{Acknowledgments}

This paper is based on part of a dissertation submitted by the first author to the University of Massachusetts-Dartmouth in partial fulfillment of the requirements for the degree of Doctor of Philosophy. Tagging of basking sharks would not have been possible without the cooperation and expertise of J Chisholm, W Chaprales and E Lott (FN Ezyduzit), and spotter pilots T Voorheis, G Breen, and W Davis. We thank D Bernal, G Cowles, J Kelly, J Kneebone, B Galuardi, T Lam, and Y Papastamatiou for helpful suggestions on the tracking and habitat analyses. D Szumylo provided valuable assistance with GIS. Comments provided by two anonymous reviewers improved the manuscript. For access to satellite-derived environmental data sets, we acknowledge NOAA's CoastWatch, National Ocean Service, and National Oceanographic Data Center, and NASA. Funding for this research was provided by NASA (Grant NNS06AA96G) and Federal Aid in Sportfish Restoration, and financial support for the first author was provided by the NOAA Advanced Studies Program and the National Marine Fisheries Service's Greater Atlantic Regional Fisheries Office. Field work was conducted under permits from the National Marine Fisheries Service's Atlantic Highly Migratory Species Division and the Massachusetts Division of Marine Fisheries. This is Massachusetts Division of Marine Fisheries Contribution Number 50.

\section{Author details}

${ }^{1}$ Department of Fisheries Oceanography, School for Marine Science and Technology, University of Massachusetts - Dartmouth, Fairhaven, MA, USA. ${ }^{2}$ Department of Marine Sciences, University of New England, Biddeford, ME 04005, USA. ${ }^{3}$ Maine Department of Marine Resources, Boothbay Harbor, ME 04575, USA. "Massachusetts Division of Marine Fisheries, New Bedford, MA 02744, USA. ${ }^{5}$ National Oceanic and Atmospheric Administration, National Marine Fisheries Service, Greater Atlantic Regional Fisheries Office, Gloucester, MA 01930, USA.

Received: 23 December 2013 Accepted: 7 July 2014

Published: 24 July 2014

\section{References}

1. Meise-Munns C, Green J, Ingham M, Mountain D: Interannual variability in the copepod populations of Georges Bank and the western Gulf of Maine. Mar Ecol Prog Ser 1990, 65:225-232.

2. Kenney RD, Wishner KF: The South Channel ocean productivity experiment. Cont Shelf Res 1995, 15:373-384.

3. Eckert SA, Stewart BS: Telemetry and satellite tracking of whale sharks, Rhincodon typus, in the Sea of Cortez, Mexico, and the North Pacific Ocean. Environ Biol Fish 2001, 60:299-308.

4. Firestone J, Lyons SB, Wang C, Corbett JJ: Statistical modeling of North Atlantic right whale migration along the mid-Atlantic region of the eastern seaboard of the United States. Biol Cons 2008, 141:221-232.

5. Skomal GB, Zeeman SI, Chisholm JH, Summers EL, Walsh HJ, McMahon KW, Thorrold SR: Transequatorial migrations by basking sharks in the western Atlantic Ocean. Curr Biol 2009, 19:1-4.

6. Sleeman JC, Meekan MG, Wilson SG, Polovina JJ, Stevens JD, Boggs GS, Bradshaw CJA: To go or not to go with the flow: environmental influences on whale shark movement patterns. J Exp Mar Biol Ecol 2010, 390:84-98.

7. Baumgartner MF, Mayo CA, Kenney RD: Enormous carnivores, microscopic food, and a restaurant that's hard to find. In The Urban Whale: North Atlantic Right Whales at the Crossroads. Edited by Kraus SD, Rolland RM. Cambridge: Harvard University Press; 2007:138-171.

8. Sims DW, Witt MJ, Richardson AJ, Southall EJ, Metcalfe JD: Encounter success of free-ranging marine predator movements across a dynamic prey landscape. Proc R Soc B 2006, 273:1195-1201.

9. Kempster RM, Collin SP: Electrosensory pore distribution and feeding in the basking shark Cetorhinus maximus (Lamniformes: Cetorhinidae). Aquat Biol 2011, 12:33-36.

10. Compagno LJV: Sharks of the World: An Annotated and Illustrated Catalogue of Shark Species Known to Date, Volume 2. Rome: FAO; 2001.

11. Bigelow HB, Schroeder WC: Fishes of the Gulf of Maine. Fish Bull 1953, $53: 1-577$.
12. Owen RE: Distribution and Ecology of the Basking Shark Cetorhinus maximus (Gunnerus 1765), MSc thesis: University of Rhode Island; 1984.

13. Kenney RD, Owen RE, Winn HE: Shark distributions off the northeast United States from marine mammal surveys. Copeia 1985, 1985:220-223.

14. Wilson SG: Basking sharks (Cetorhinus maximus) schooling in the southern Gulf of Maine. Fish Oceanogr 2004, 13:283-286.

15. Baduini CL: Feeding Ecology of the Basking Shark (Cetorhinus maximus) Relative to Distribution and Abundance of Prey, MSc Thesis: San Jose State University; 1995.

16. Siders ZA, Westgate AJ, Johnston DW, Murison LD, Koopman HN: Seasonal variation in the spatial distribution of basking sharks (Cetorhinus maximus) in the lower Bay of Fundy. Canada. PLOS ONE 2013, 8(12):e82074. doi:10.1371/journal.pone.0082074.

17. Sims DW: Tracking and analysis techniques for understanding free-ranging shark movements and behavior. In Sharks and Their Relatives II. Edited by Carrier JC, Musick JA, Heithaus MR. Boca Raton: CRC Press; 2010:351-392.

18. Hammerschlag N, Gallagher AJ, Lazarre DM: A review of shark satellite tagging studies. J Exp Mar Biol Ecol 2011, 398:1-8.

19. Papastamatiou YP, Lowe CG: An analytical and hypothesis-driven approach to elasmobranch movement studies. J Fish Biol 2012, 80:1342-1360.

20. Bonfil R, Meyer M, Scholl MC, Johnson R, O'Brien S, Oosthuizen H, Swanson S, Kotze D, Paterson M: Transoceanic migration, spatial dynamics, and population linkages of white sharks. Science 2005, 310:100-103.

21. Weng KC, Foley DG, Ganong JE, Perle C, Shillinger GL, Block BA: Migration of an upper trophic level predator, the salmon shark Lamna ditropis, between distant ecoregions. Mar Ecol Prog Ser 2008, 372:253-264.

22. Domeier ML, Nasby-Lucas N: Two-year migration of adult female white sharks (Carcharodon carcharias) reveals widely separated nursery areas and conservation concerns. Animal Biotelemetry 2013, 1:2.

23. Priede IG: A basking shark (Cetorhinus maximus) tracked by satellite together with simultaneous remote sensing. Fish Res 1984, 2:201-216.

24. Priede IG, Miller PI: A basking shark (Cetorhinus maximus) tracked by satellite together with simultaneous remote sensing II: new analysis reveals orientation to a thermal front. Fish Res 2009, 95:370-372.

25. Sims DW, Southall EJ, Richardson AJ, Reid PC, Metcalfe JD: Seasonal movements and behavior of basking sharks from archival tagging: no evidence of winter hibernation. Mar Ecol Prog Ser 2003, 248:187-196.

26. Sims DW, Southall EJ, Tarling GA, Metcalfe JD: Habitat-specific normal and reverse diel vertical migration in the plankton-feeding basking shark. J Anim Ecol 2005, 74:755-761.

27. Southall EJ, Sims DW, Metcalfe JD, Doyle JI, Fanshawe S, Lacey C, Shrimpton J, Solandt JL, Speedie CD: Spatial distribution patterns of basking sharks on the European shelf: preliminary comparison of satellite-tag geolocation, survey and public sightings data. J Mar Biol Ass UK 2005, 85:1083-1088.

28. Southall EJ, Sims DW, Witt MJ, Metcalfe JD: Seasonal space-use estimates of basking sharks in relation to protection and political-economic zones in the North-east Atlantic. Biol Cons 2006, 132:33-39.

29. Gore MA, Rowat D, Hall J, Gell FR, Ormond RF: Transatlantic migration and deep mid-ocean diving by basking shark. Biol Lett 2008, 4:395-398.

30. Skomal GB, Wood G, Caloyianis N: Archival tagging of a basking shark, Cetorhinus maximus, in the western North Atlantic. J Mar Biol Ass UK 2004, 84:795-799.

31. Teo SLH, Boustany A, Blackwell S, Walli A, Weng KC, Block BA: Validation of geolocation estimates based on light level and sea surface temperature from electronic tags. Mar Ecol Prog Ser 2004, 283:81-98.

32. Sims DW, Quayle VA: Selective foraging behavior of basking sharks on zooplankton in a small-scale front. Nature 1998, 393:460-464.

33. Sims DW: Threshold foraging behavior of basking sharks on zooplankton: life on an energetic knife-edge? Proc R Soc Lond B 1999, 266:1437-1443.

34. Sims DW: Filter-feeding and cruising swimming speeds of basking sharks compared with optimal models: they filter-feed slower than predicted for their size. J Exp Mar Biol Ecol 2000, 249:65-76.

35. Simpson JJ: Remote sensing in fisheries: a tool for better management in the utilization of a renewable resource. Can J Fish Aquat Sci 1994, 51:743-771.

36. Santos AM: Fisheries oceanography using satellite and airborne remote sensing methods: a review. Fish Res 2000, 49:1-20.

37. Kobayashi DR, Polovina JJ, Parker DM, Kamezaki N, Cheng I, Uchida I, Dutton $\mathrm{PH}$, Balazs GH: Pelagic habitat characterization of loggerhead sea turtles, Caretta caretta, in the North Pacific Ocean (1997 to 2006): insights from satellite tag tracking and remotely sensed data. J Exp Mar Biol Ecol 2008, 356:96-114 
38. Lehodey P, Senina I, Calmettes B, Royer F, Gaspar P, Abecassis M, Polovina J, Parker D, Domokos R, Hernandez O, Dessert M, Kloser R, Young J, Lutcavage M, Handegard NO, Hampton J: Towards operational management of pelagic ecosystems. ICES 2010, A:04.

39. Graham RT, Witt MJ, Castellanos DW, Remolina F, Maxwell S, Godley BJ, Hawkes LA: Satellite tracking of manta rays highlights challenges to their conservation. PLOS ONE 2012, 7:e36834. doi:10.1371/journal.pone.0036834.

40. Campana SE, Joyce W, Fowler M: Subtropical pupping ground for a cold-water shark. Can J Fish Aquat Sci 2010, 67:769-773.

41. Baumgartner MF, Mate BR: Summer and fall habitat of North Atlantic right whales (Eubalaena glacialis) inferred from satellite telemetry. Can J Fish Aquat Sci 2005, 62:527-543

42. McKinney JA, Hoffmayer ER, Wu W, Fulford R, Hendon J: Feeding habitat of the whale shark Rhincodon typus in the northern Gulf of Mexico determined using species distribution modeling. Mar Ecol Prog Ser 2012, 458:199-211.

43. Humphries NE, Queiroz N, Dyer JRM, Pade NG, Musyl MK, Schaefer KM, Fuller DW, Brunnschweiler JM, Doyle TK, Houghton JDR, Hays GC, Jones CS, Noble LR, Wearmouth VJ, Southall EJ, Sims DW: Environmental context explains Lévy and Brownian movement patters of marine predators. Nature 2010, 465:1066-1069.

44. Sims DW: Sieving a living: a review of the biology, ecology, and conservation status of the plankton-feeding basking shark Cetorhinus maximus. Adv Mar Biol 2008, 54:171-220.

45. Friedland KD, Stock C, Drinkwater KF, Link JS, Leaf RT, Shank BV, Rose JM, Pilskaln $\mathrm{CH}$, Fogarty MJ: Pathways between primary production and fisheries yields in large marine ecosystems. PLOS ONE 2012, 7:e28945. doi:10.1371/journal.pone.0028945.

46. Turner JT, Borkman DG, Libby PS: Zooplankton trends in Massachusetts Bay, USA: 1998 to 2008. J Plankton Res 2011, 33:1066-1080.

47. Sherman K, Solow A, Jossi J, Kane J: Biodiversity and abundance of the zooplankton of the Northeast Shelf ecosystem. ICES J Mar Sci 1998, 55:730-738.

48. Pershing AJ, Record NR, Monger BC, Mayo CA, Brown MW, Cole TVN, Kenney RD, Pendleton DE, Woodward LA: Model-based estimates of right whale habitat use in the Gulf of Maine. Mar Ecol Prog Ser 2009, 378:245-257.

49. Sims DW, Merrett DA: Determination of zooplankton characteristics in the presence of surface feeding basking sharks Cetorhinus maximus. Mar Ecol Prog Ser 1997, 158:297-302.

50. Lynch DR, Gentleman WC, McGillicuddy DJ, Davis CS: Biological/physical simulations of Calanus finmarchicus population dynamics in the Gulf of Maine. Mar Ecol Prog Ser 1998, 169:189-210.

51. Jiang M, Brown MW, Turner JT, Kenney RD, Mayo CA, Zhang Z, Zhou M: Springtime transport and retention of Calanus finmarchicus in Massachusetts and Cape Cod Bays, USA, and implications for right whale foraging. Mar Ecol Prog Ser 2007, 349:183-197.

52. Matthews LH: Reproduction in the basking shark, Cetorhinus maximus (Gunner). Phil Trans R Soc Lond B 1950, 234:247-316.

53. Harvey-Clark CJ, Stobo WT, Helle E, Mattson M: Putative mating behavior in basking sharks off the Nova Scotia coast. Copeia 1999, 3:780-782.

54. Sims DW, Southall EJ, Quayle VA, Fox AM: Annual social behavior of basking sharks associated with coastal front areas. Proc $R$ Soc Lond $B$ 2000, 267:1897-1904.

55. Gallager SM, Davis CS, Epstein AW, Solow A, Beardsley RC: High-resolution observations of plankton spatial distributions correlated with hydrography in the Great South Channel, Georges Bank. Deep-Sea Res I/ 1996, 43:1627-1663.

56. Gallager SM, Yamazaki H, Davis CS: Contribution of fine-scale vertical structure and swimming behavior to formation of plankton layers on Georges Bank. Mar Ecol Prog Ser 2004, 267:27-43.

57. Norrbin MF, Davis CS, Gallager SM: Differences in fine-scale structure and composition of zooplankton between mixed and stratified regions of Georges Bank. Deep-Sea Res II 1996, 43:1905-1924.

58. Manning JP, Beardsley RC: Assessment of Georges Bank recirculation from Eulerian current observations in the Great South Channel. Deep-Sea Res II 1996, 43:1575-1600.

59. Baumgartner MF, Lysiak NSF, Schuman C, Urban-Rich J, Wenzel FW: Diel vertical migration behavior of Calanus finmarchicus and its influence on right and sei whale occurrence. Mar Ecol Prog Ser 2011, 423:167-184.
60. Durbin EG, Campbell RG, Gilman SL, Durbin AG: Diel feeding behavior and ingestion rate in the copepod Calanus finmarchicus in the southern Gulf of Maine during late spring. Cont Shelf Res 1995, 15:539-570.

61. Hazen EL, Jorgensen SJ, Rykaczewski RR, Bograd SJ, Foley DG, Jonsen ID, Shaffer SA, Dunne JP, Costa DP, Crowder LB, Block BA: Predicted habitat shifts of Pacific top predators in a changing climate. Nat Clim Chang 2012. doi:10.1038/nclimate1686.

62. Behrenfeld MJ, Falkowski PG: A consumer's guide to phytoplankton primary productivity models. Limnol Oceanogr 1997, 42:1479-1491.

63. Kenney RD: Right whales and climate change: facing the prospect of a greenhouse future. In The Urban Whale: North Atlantic Right Whales at the Crossroads. Edited by Kraus SD, Rolland RM. Cambridge: Harvard University Press; 2007:436-459.

64. Ji R, Edwards M, Mackas DL, Runge JA, Thomas AC: Marine plankton phenology and life history in a changing climate: current research and future directions. J Plankton Res 2010, 32:1355-1368.

65. Capotondi A, Alexander MA, Bond NA, Curchitser EN, Scott JD: Enhanced upper ocean stratification with climate change in the CMIP3 models. J Geophys Res 2012, 117:C04031. doi:10.1029/2011JC007409.

66. Witt MJ, Akesson S, Broderick AC, Coyne MS, Ellick J, Formia A, Hays GC, Luschi P, Stroud S, Godley BJ: Assessing accuracy and utility of satellite-tracking data using Argos-linked Fastloc-GPS. Anim Behav 2010, 80:571-581

67. Chaprales W, Lutcavage M, Brill R, Chase B, Skomal G: Harpoon method for attaching ultrasonic and 'popup' satellite tags to giant bluefin tuna and large pelagic fishes. Mar Tech Soc J 1998, 32:104-105.

68. Friedland $K D$, Hare JA: Long-term trends and regime shifts in the sea surface temperature on the continental shelf of the northeast United States. Cont Shelf Res 2007, 27:2313-2328.

69. Kann LM, Wishner K: Spatial and temporal patterns of zooplankton on baleen whale feeding grounds in the southern Gulf of Maine. J Plankton Res 1995, 17:235-262.

70. Castelao RM, Barth JA, Mavor TP: Flow-topography interactions in the northern California current system observed from geostationary satellite data. Geophys Res Lett 2005, 32:L24612. doi:10.1029/2005GL024401.

71. Kilpatrick KA, Podesta GP, Evans R: Overview of the NOAA/NASA advanced very high resolution radiometer pathfinder algorithm for sea surface temperature and associated matchup database. J Geophys Res-Oceans 2001, 106:9179-9197.

72. Gordon HR, Wang M: Retrieval of water-leaving radiance and aerosol optical thickness over the oceans with SeaWiFS: a preliminary algorithm. Appl Opt 1994, 33:443-452.

73. Amante C, Eakins BW: ETOPO1 1 Arc-Minute Global Relief Model: Procedures, Data Sources and Analysis. NOAA Tech Memo NESDIS NGDC-24 2009. National Geophysical Data Center, NOAA. doi:10.7289/N5C8276M

74. Rooney SM, Wolfe A, Hayden TJ: Autocorrelated data in telemetry studies: time to independence and the problem of behavioural effects. Mamm Rev 1998, 28:89-98.

75. Aarts G, MacKenzie M, McConnel B, Fedak M, Matthiopoulos J: Estimating space-use and habitat preferences from wildlife telemetry data. Ecography 2008, 31:140-160.

76. Krebs CJ: Ecological Methodology. 2nd edition. Menlo Park: Addison Wesley Longman; 1999.

77. Heithaus MR, Hamilton IM, Wirsing AJ, Dill LM: Validation of a randomization procedure to assess animal habitat preferences: microhabitat use of tiger sharks in a seagrass ecosystem. J Anim Ecol 2006, 75:666-676.

78. Curtis TH, Parkyn DC, Burgess GH: Use of human-altered habitats by bull sharks in a Florida nursery area. Mar Coast Fish 2013, 5:28-38.

79. Beyer HL: Geospatial Modelling Environment (Version 0.7.2.1, 2012). http://www.spatialecology.com/gme.

80. Sokal RR, Rohlf FJ: Biometry. 3rd edition. New York: WH Freeman and Company; 2005

81. Zar JH: Biostatistical Analysis. 4th edition. Upper Saddle River: Prentice-Hall, Inc; 1999.

doi:10.1186/2050-3385-2-12

Cite this article as: Curtis et al:: Eyes in the sky: linking satellite oceanography and biotelemetry to explore habitat selection by basking sharks. Animal Biotelemetry 2014 2:12. 